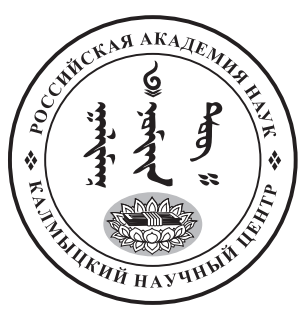

Published in the Russian Federation

Oriental Studies (Previous Name: Bulletin of the Kalmyk Institute

for Humanities of the Russian Academy of Sciences)

Has been issued as a journal since 2008

ISSN: 2619-0990; E-ISSN: 2619-1008

Vol. 14, Is. 3, pp. 626-634, 2021

Journal homepage: https://kigiran.elpub.ru

УДК / UDC 398.8

DOI: $10.22162 / 2619-0990-2021-55-3-626-634$

\title{
К вопросу о создании образа героя башкирской волшебной сказки
}

\section{Гульнур Равиловна Хусаинова ${ }^{1}$}

${ }^{1}$ Институт истории, языка и литературы Уфимского федерального исследовательского центра РАН (д. 71, пр. Октября, 450054 Уфа, Российская Федерация)

доктор филологических наук, заведующий отделом

iD 0000-0002-0290-1844. E-mail: bashfolk@yandex.ru

(C) КалмНЦ РАН, 2021

(C) Хусаинова Г. Р., 2021

Аннотация. Введение. Для языка народной волшебной сказки характерно широкое использование изобразительных средств, в том числе эпитетов, которое объясняется мировоззрением, эстетическими представлениями, определенными понятиями, сложившимися в ходе исторического развития народа, с народной философией, особенностями языка. До настоящего времени изучение художественно-изобразительных средств именно башкирских волшебных сказок специально не проводилось, в связи с чем статья посвящена вопросу изучения эпитетов башкирской народной волшебной сказки, которые придают образную выразительность языку сказки. Целью исследования является выявление и рассмотрение эпитетов, характеризующих главного героя сказки с разных сторон, по методике А. И. Алиевой, а также определение структурных типов эпитетов волшебных сказок башкир по методике алтайской исследовательницы М. А. Демчиновой. Материалы и методы. В качестве материала исследования использованы тексты башкирских волшебных сказок, опубликованные в двух книгах научного свода «Башкирское народное творчество» на башкирском языке. В работе применялись текстологический, аналитический методы исследования. Результаты. В процессе работы над статьей из двух книг сказок научного свода «Башкирское народное творчество» выявлены эпитеты. Основательно рассмотрены эпитеты, характеризующие главного героя: его внешность, семейное положение, социальный статус, его одежду, жилище и др. Совокупность эпитетов, характеризующих героя башкирской волшебной сказки, предстает как система. Комплексная характеристика героя народной сказки представляется в определенной последовательности и создает образ идеального героя, который, несмотря на бедность, добр, щедр и готов всегда прийти на помощь нуждающемуся. Во второй части статьи эпитеты рассматриваются по структурному типу и выделяются простые, сложные эпитеты.

Ключевые слова: фольклор, сказка, волшебная сказка, башкирская сказка, язык, изобразительные средства, эпитет, простой, сложный, главный герой, характеристика, структурный тип, формульные конструкции 
Благодарность. Исследование проведено в рамках государственной субсидии - проект «Духовная культура тюркских народов Южного Урала» (номер госрегистрации: АААА-А17-117040350082-3).

Для цитирования: Хусаинова Г. Р. К вопросу о создании образа героя башкирской волшебной сказки // Oriental Studies. 2021. T. 14. № 3. C. 626-634. DOI: 10.22162/2619-0990-2021-55-3-626634

\title{
Hero in Bashkir Magic Tale: Means of Artistic Manifestation Revisited
}

\author{
Gulnur R. Khusainova ${ }^{1}$
}

${ }^{1}$ Institute of History, Language and Literature of the Ufa Federal Research Centre of the RAS (71, Oktyabrya Ave., 450054 Ufa, Russian Federation)

Dr. Sc. (Philology), Head of Department

(iD) 0000-0002-0290-1844.E-mail: bashfolk@yandex.ru

\author{
(C) KalmSC RAS, 2021 \\ (C) Khusainova G. R., 2021
}

\begin{abstract}
Introduction. The language of the folk magic tale is characterized by a wide use of artistic means, including epithets; this may be explained by the worldview, aesthetic ideas, certain concepts that developed in the course of the people's history, as well as with folk philosophy and the specific features of the language. So far there has been no special study devoted to imaginative-expressive means of Bashkir magic tales; hence, to fill in the gap, the present article undertakes the study of epithets of the stock of artistic means characteristic of the Bashkir folk magic tale that add to the expressiveness of the language in magic tales. Thus, the study aims at identifying and analyzing epithets that characterize the main character of the magic tale from different sides; A. I. Aliyeva's method has proved useful for this part of the research, while the examination of their structural types draws on the method elaborated by the Altai researcher M. A. Demchinova. Data and research methods. The sources for the research data were the texts of magic tales published in the Bashkir language in the two books of the scholarly collection Bashkir Folk Art; the analysis of the data was carried out with the help of textual and analytical methods. Results. The texts of the tales were examined first to identify epithets; then, the analysis focused on the epithets that characterize the main character: their appearance, marital status, social status, clothing, housing, etc. It appears that the epithets that characterize the protagonists in Bashkir magic tales have a systemic character. There is a certain sequence in the complex portrayals of personages that help to create the image of an ideal hero who may be poor but, also, kind, generous, and always ready to help those in need. The second part of the article focuses on the structural types of the items, including simple and complex epithets. Each of the type is illustrated with examples.

Keywords: folklore, folk tale, magic tale, Bashkir tale, language, artistic means, epithet, simple epithet, complex epithet, main character, portrayal, structural type, formula

Acknowledgements. The reported study was funded by government subsidy — project name 'Turkic Peoples of the Southern Urals: Spiritual Culture' (state reg. no. AAAA-A17-117040350082-3).

For citation: Khusainova G. R. Hero in Bashkir Magic Tale: Means of Artistic Manifestation Revisited. Oriental Studies. 2021. Vol. 14 (3): 626-634. (In Russ.). DOI: 10.22162/2619-0990-202155-3-626-634
\end{abstract}

\section{है}

\section{Введение}

В системе художественных средств башкирской волшебной сказки эпитеты являются одним из основных приемов созда- ния образности. Сопутствуя определяемому слову, эпитет характеризует, оценивает, индивидуализирует предмет, явление или человека, перенося на определяемое слово 
свое значение и участвуя в создании определенного художественного образа. Портретные характеристики сказочных персонажей влияют на формирование этнокультурных представлений об облике человека вообще и открывают народный взгляд и на человека, и на мир в целом [Мещерякова 2017: 359].

Язык башкирских народных сказок рассматривался в отдельных лингвистических статьях [Киекбаев 1966; Зайнуллин 1974; Зайнуллин 1976; Псянчин 1984; Галяутдинов 2000; Ягафарова 2016; Кульсарина 2009; Кульсарина 2020].

В башкирской фольклористике данный аспект поэтики жанра сказки специально, но лишь частично рассмотрен Н. Т. Зариповым на материале башкирской богатырской сказки. Резко контрастное изображение всего в богатырской сказке обусловило изучение автором антитезы и гиперболы - «традиционных способов художественного воплощения противоположных эстетических категорий героического и низменного, прекрасного и безобразного, высокого и низкого и т. д.» [Зарипов 2008: 209].

Рассмотрению сравнений и гипербол в башкирской богатырской сказке посвящена статья молодого исследователя Р. Р. Зинуровой [Зинурова 2009].

Цель данной статьи - показать систему изобразительных средств, характеризующих героя башкирской волшебной сказки.

Источником для исследования послужили две книги волшебных сказок научного свода «Башкирское народное творчество» на языке оригинала. Дословный перевод примеров с башкирского языка на русский осуществлен автором статьи.

В работе применялись текстологический, аналитический методы исследования.

\section{Социальная характеристика героя}

Самый яркий и запоминающийся образ волшебной сказки - это главный герой, который воплощает в себе народные представления о справедливости, доброте, верности и становится художественным выражением идеала. Положительные черты, присущие герою одного сюжета, повторяются в героях других сказок, т. е. в сказках изображается единый народный характер, который нашел воплощение в разных типах героев.

Основной герой волшебной сказки, в сущности, один: обобщенный собиратель- ный образ положительного героя. Мужественный, добрый, справедливый, красивый герой преодолевает трудные препятствия на своем пути и достигает своей цели: добывает целебное средство, женится на царевне, побеждает врага родины. Герой этот един, независимо от того, беден он или богат, женат или не женат, борется с мифическими существами или выполняет трудное задание царя.

Исследователь А. И. Алиева выделяет три типа положительных героев [Алиева 1986: 62], которые характерны и башкирской волшебной сказке: герой-богатырь, который ищет похищенную сестру («Булансы Мэргэн»), дочь падишаха («Умыс», «Молниеносный меч»), жену/невесту («Ез̧тырнак», «Зайнулла и Красата», «Сайфелмулюк», «Биранхылу — дочь бире»); «иронический удачник», многократно демонстрирующий свое превосходство над теми, кто прежде мог куражиться над ним (старшие братья или старшие зятья) («Златохвостый-Серебряногривый», «Незнай», «Таз батыр», «Кинзебулат»); герой, который достигал цели с помощью чудесных предметов или помощников («Умный кот и Плешивый», «Яшма», «Волшебный перстень»).

Главный герой волшебной сказки обычно бывает из народа и социально обездоленным, что подтверждается на материале башкирской сказки и с помощью эпитетов. Например, эпитет часто характеризует героя как единственного сына: бер егет / бер ул 'один парень / один сын' [БХИ 1976, I: 99, 116. 145, 264, 101, 102, 148, 187; БХИ 1976, II: 29, 39], карттын уль 'сын старика' [БХИ 1976, I: 180, 292], а также акцентирует внимание на социальном происхождении героя: бер етем малай йәшәгән 'один мальчик-сирота жил’ [БХИ 1976, I: 257], бер ярль вына егет 'один бедный парень' [БХИ 1976, I: 118, 270], бер йолкош, иң түбдн егет 'нищий, молодой человек низкого происхождения’ [БХИ 1976, II: 188]. В последнем примере использован эпитет «бедный» по отношению к главному герою башкирской волшебной сказки, но есть сказки, в которых называется род занятий, указывающий на низкий социальный статус героя: малай өйзән-өйгә йөрөп hораньлn тамак туйзъьрван 'мальчик ходил по домам, попрошайничал, чтоб прокормить себя’ [БХИ 1976, 
I: 257], хезмлтсе малай 'мальчик-прислуга' [БХИ 1976, I: 152], в большинстве сказок он является охотником [БХИ 1976, I: 97, 99, 104, 112. 116, 129, 144, 148, 163, 167, 169, 197, 305; БХИ 1976, II: 85, 152, 209, 268] и очень редко иген игә 'занимался хлебопашеством’ [БХИ 1976, II: 164], урмансы булган 'лесником был' [БХИ 1976, I: 250, 272].

Низкое социальное положение героя в некоторых сказках показывается через характеристику его родителей: ярль булгандар 'бедные были' [БХИ 1976, II: 81, 161], фәкир карт йәшәгән 'бедный старик жил' [БХИ 1976, І: 307], ул йыл да һарык көтә uне, mu 'он каждый год пас овец' [БХИ 1976, I: 128], одежде: кейгән кейеме куян тиреһенән тегелгән 'одежда на нем была из заячьей шкуры’ [БХИ 1976, I: 99], кейер кейеме булмаван 'одевать одежды не было' [БХИ 1976, І: 228], аягындавы катаһынан башка байльвы булмаван 'кроме кожаных галош на ногах, другого богатства не было’ [БХИ 1976, I: 307]; наличию имущества: торор ере булмаган 'ему негде было жить' [БХИ 1976, II: 136], әсәһенән калган күк hыŭыр 'оставшаяся от матери сивая корова' [БХИ 1976, I: 228]; характеристике жилища: кыли һыуылтан, йәй ямдырзан һаклар ете терәу өйө булван 'дом с семью подпорками, который спасал зимой от холода, летом — от дождя' [БХИ 1976, I: 253]; по описанию их жизни и быта: бик ярль йәшәгәндәр 'жили очень бедно' [БХИ 1976, I: 167], ас-яланвас вүмер итә биргән 'жили в голоде, одежду не имели' [БХИ 1976, I: 222], бабай һунарва йөрөгән, вак-төйәк йәнлек альл кайткан, шуның менән көн күргәндәр 'старик на охоту ходил, мелких зверюшек приносил, чем и питались' [БХИ 1976, I: 253]; өй эсе шундай който, Үгез мөгөзөнд элеп сыгырлык сепрәк-сапрак заты юж “дом был неприглядным, внутри было пусто, не нашлось бы тряпки, которую можно было бы зацепить за рога быка' [БХИ 1976, II: 277], фәкир генә көн күргәндәр 'жили в нищете' [БХИ 1976, II: 147, 161, 210]. Во всем этом содержится особый смысл. Отсутствие одежды, еды, питья не только подчеркивает аскетизм его жизни, но и становится знаком жизни праведной [Мещерякова 2017: 364].

Перечисленные выше примеры показывают степень бедности главного героя. Однако очень скоро он богатеет - таков сюжетный поворот в сказке. Вместе с тем богатство героя сказки никогда не описывается. Очень редко подчеркивается, что у него были стада или табуны. Он никогда не стремится за богатством, потому что в сказке достоинством героя является не богатство, а храбрость, смекалка, находчивость и вообще лучшие нравственные качества. Цель же героя сказки: делать добрые дела, спасать попавшего в беду, помогать нуждающимся.

В ряде сказок герой является человеком высокого статуса: батша ульл 'царский сын (царевич' [БХИ 1976, I: 156, 163; БХИ 1976, II: 43, 50, 52, 101, 110], саузагәр ульл 'сын купца' [БХИ 1976, I: 152; БХИ 1976, II: 50, 92, 95], бик бай бер кеше йәшәгән 'жил один очень богатый человек’ [БХИ 1976, I: 261; БХИ 1976, ІІ: 104].

В одной сказке мальчика-сироту берет на воспитание сам царь: батша Зәйнуллань Үзззәренен уль итергә, кейендереп, укытып, Үзенд алмашка әзееллргә ниәт иткән 'царь решил усыновить, переодеть, выучить мальчика и подготовить себе на смену' [БХИ 1976, I: 257], т. е. по случайному везению низкий статус героя меняется на высокий. Несмотря на высокий статус, герой ничем не отличается от героя низкого статуса. Цель и функции у них одинаковы.

В сказках иногда герою дается оценочная характеристика: ТҮземгол Үзе матур, Үзе батыр, кыйыу зза, сос та булган. Кульннан килмәгән эше булмаван уның 'Туземгул сам был и красивый, и смелый, и ловкий. На все руки мастер был' [БХИ 1976, I: 169], ezет шундай һыльуу, көслө, шундай мөһабәт, ти 'очень красивый, сильный, величественный молодой человек’ [БХИ 1976, I: 255], теремек тә, акылль ла малай 'шустрый, умный мальчик' [БХИ 1976, I: 257], саф күңелле, таза фекерле, тыңллаусан ульм 'мой с чистой душой, со светлыми помыслами послушный сын' [БХИ 1976, II: 139], бынамын тигән егет: иул тиклем мөһабәт, иул тиклем матур, дйтеп бөтөргөһөз! 'превосходный молодой человек: такой статный, такой красивый, словами не описать!' [БХИ 1976, II: 188].

Как видно из примеров, герой волшебной сказки наделен только положительными чертами с помощью эпитетов «красивый», «смелый», «ловкий», «умный», «сильный» и т. д. 
И конь у него красивый, особенный: ис киткес матур колон - алтын койрокло, көмөш ялль 'очень красивый жеребенок златохвостый и серебряногривый' [БХИ 1976, II: 20], бывает он разной окраски: күк 'белый', hapbl 'сивый', кола 'саврасый' [БХИ 1976, II: 124], кара 'черный' [БХИ 1976, II: 138], ерән 'рыжий' [БХИ 1976, II: 140].

Одна из важных особенностей создания сказочных образов и предметов в том, что оно построено на мифологических представлениях народа. В большинстве случаев в волшебных сказках герои рождались чудесным образом (от съеденного родителями чудесного яблока, рыбы и т. д.), могли иметь золотые волосы, серебряные зубы; героини способны были оставлять в своем следе золото, а герой — расти не по дням, а по часам. Только в волшебных сказках имели место такие волшебные предметы, как: сапоги-скороходы, летающие кошмы, летающие лодки, летающие кони, с помощью которых герой добирался туда, куда ему надо; шапка-невидимка, делавшая героя невидимым; лебединое молоко, хрустальный мост, медовые реки, молочное озеро, добытые героем по требованию царя; золотой, серебряный, медный леса, которые герой проходил на своем пути и т. д. Крылатые кони, например, с давних времен были частью мифологии многих культур и были напрямую связаны с божествами, и о них обычным людям известно мало. В башкирском фольклоре это был тулпар, крылья которого никто не должен был видеть, иначе он погибал.

Эпитет как основное изобразительное средство создания образности

Интересна методика изучения эпитетов в алтайской волшебной сказке у М. А. Демчиновой, которая рассматривает их по структурному типу. Например, цветовые эпитеты она делит на: простые, состоящие из определяемого и определяющего слов, и сложные, являющиеся по своему составу сложными [Демчинова 2003: 80]. Данная методика приемлема и при изучении башкирских волшебных сказок.

В волшебных сказках башкир часто встречаются простые эпитеты типа hылыly жыз 'красивая девушка', ярль егет 'бедный егет', затлы кейем 'дорогая одежда', бейек тау 'высокая гора', кара урман 'густой лес', кара болот 'черное облако' и т. д. Они описывают явления и предметы окружающего мира, выделяя их существенные признаки. В подобных эпитетах наблюдается тенденция одинакового восприятия предмета.

В башкирской волшебной сказке постоянные эпитеты используются для определения цвета: кыззыл haндык 'красный сундук', aк йылан 'белый змей' (по представлениям башкир, это царь змей, священная змея. Он встречается редко кому и приносит счастье, если перед ним успеть постелить белый платок, где он оставляет свой рог, который необходимо беречь [Надршина 1986: 101]), куныыр hыйыр 'бурая корова' (священное животное, в котором заключалось благополучие, плодовитость табуна); возраста: ике йөз йәилек әбей 'двухсотлетняя старуха'; выражения физического и духовного состояния персонажей: көслө егет 'сильный парень', бахыр килен 'несчастная невестка'; отображения внешности: шазра битле 'рябая девушка'; указания на качество-сущность: алйот таз 'глупый плешивый', убырлы мулла 'мулла-людоед’, количество, длину, высоту, величину и материал: $у н$ ике башль дейеү 'двенадцатиголовый дэв', кырк коласльг сынйыр 'сорокааршинная цепь', бас̧ырау буйы ер 'расстояние со слеги', ат башындай алтын 'золото величиной с конскую голову' (один из примеров о представлении башкирами богатства) и т. д.

Излюбленным эпитетом башкир, как и у многих народов, являются слова алтын 'золотой' и көмөш 'серебро: алтын башль, көмөш күтле 'золотоголовый, с серебряным задом', алтын сәсле 'с золотыми волосами' [БХИ 1976, I: 85] , алтын эзु 'золотой след', көмөш тешле 'с серебряными зубами', көмөш таяк 'серебряная палка' [БХИ 1976, I: 231], золотыми в башкирской волшебной сказке бывают дворец, дом, ложка, лес, птица, рыбка, клетка, кольцо и т. д. Они ориентированы на представление о мифологическом содержании соответствующих людей, животных и предметов. Золото и серебро наделялись свойствами оберега, ассоциировались у русских со здоровьем, крепостью и чистотой [Мещерякова 2017: 362], у башкир серебро, например, тоже выполняло обережно-отгонную функцию, поэтому в национальной одежде башкирки было много серебра, которое, по народному поверью, 
оберегало невесту от сглаза, нечистых сил и болезней. Предметы же из золота, очень качественные и хорошие, в народном понимании принадлежали именно миру сказки.

Сложные эпитеты имеют следующие разновидности:

1) образованные сложением двух основ путем полного удвоения. Они имеют усиливающее значение и состоят из парных слов: озон-озон юлдар 'длинные-длинные дороги' [БХИ 1976, I: 113], матур-матур кызззар 'красивые-красивые девушки' [БХИ 1976, I: 136], өйөр-өйөр йылкы 'табун-табун лошадей’ [БХИ 1976, I: 190], өлкән-өлкән maштар 'большие-пребольшие камни' [БХИ 1976, І: 194], йоморо-йоморо йомвак 'круглый-круглый клубок' [БХИ 1976, I: 238], сокор-сакыр ерзәр 'места, где много рытвин' [БХИ 1976, I: 238]. Встречаются также сложные эпитеты, образованные путем неполного удвоения: an-aк haкалльl карт 'старик с седой-седой бородой' [БХИ 1976, I: 197, 262], йәn-йәш егет 'молодой-премолодой парень' [БХИ 1976, I: 128], йәм-йәшел авастар 'зеленые-презеленые деревья’ [БХИ 1976, I: 122], кап-кара эm 'черная-пречерная собака' [БХИ 1976, I: 248], йөзө han-hapbl булган 'лицо желтое-прежелтое стало’ [БХИ 1976, I: 266], han-hay кәйнәhе 'здоровая-прездоровая свекровь' [БХИ 1976, I: 217], тап-таза яулькк 'чистый-пречистый платок'[БХИ 1976, I: 216], mun-тигез ер 'ровная-преровная поверхность’ [БХИ 1976, І: 216].

2) составные эпитеты. Например: киң кәҮзәле, зур йозрокло һьбайль 'широкоплечий, с большим кулаком всадник’ [БХИ 1976, II: 45], күккә еткән күк hарай 'синий дворец высотой до неба’ [БХИ 1976, I: 109], утта янмай, hыузза батмай, Үзе кылыс үткәрмәй торван hувыл кейеме 'одежда воина, которая в воде не тонет, в огне не горит, мечом ее не проткнуть' [БХИ 1976, II: 30], таштары күкте тишеп торван, түбаһе лә күренмәслек тау 'гора с невидимой вершиной, с камнями, протыкающими небесный свод' [БХИ 1976, II: 38], алама бакталь ябавай бер ат 'лошадь с шерстью после весенней линьки' [БХИ 1976, I: 191], сикhез йыуан, сикһез бейек тирәк 'очень толстый, очень высокий тополь’ [БХИ 1976, I: 195], тылуган-Үскән, кендек кискән ер 'место, где родился, вырос, где пуповину перерезали' [БХИ 1976, I: 201], алть колас ала бейә 'шестиаршинная пегая кобыла' [БХИ 1976, I: 205], донъя көтөрлөк кыз Үстергән кеше йорто 'дом человека, воспитавшего достойную дочь' [БХИ 1976, I: 213], таш имсәктән ком hөm 'песочное молоко из каменного вымени' [БХИ 1976, I: 218], ер йөзөн ете әйләнгән сәмревош сукышы 'клюв самригуша, который за день семь раз облетал земной шар' [БХИ 1976, I: 224].

\section{Формульные конструкции}

В башкирских волшебных сказках имеют место также формульные конструкции, создающие своеобразный стиль и поэтику жанра. «К разряду формульных стереотипов можно отнести атрибутивные сочетания прилагательного с существительным, которые носят традиционный устойчивый характер и относятся в большинстве случаев к общефольклорному фонду, используются в разных жанрах» [Разумова 1991: 46].

В башкирском фольклоре к ним можно отнести формулы изображения удивительной красоты, богатырства, мудрости героев типа күз күрмәгән, колак ишетмәгән батыр 'слыхом не слыханый, видом не виданый батыр' [БХИ 1976, II: 127], ак hакалль, алтын акылль карт 'старик с белой бородой, золотым умом' [БХИ 1976, II: 66], an-aк йөзлө, ап-ак сәсле карт 'старик со светлым лицом, с седыми волосами' [БХИ 1976, II: 121]; способности: оста булган был hyнарсы: ауламаван йәнлеге, атмаван комо, тотмаган бальгы калмаган 'отличный был охотник: не было зверя, за которым бы он не охотился, не было птицы, которую бы он не застрелил, не было рыбы, которую бы он не поймал' [БХИ 1976, II: 191]; скорости: сабып ат етерлек, карап күз эйәрерлек түгел 'конем не догнать, взглядом не поймать' [БХИ 1976, II: 201], дальности расстояния: ат еткән ер, хат еткән ер 'место, куда конь дойдет, место, куда письмо дойдет' [БХИ 1976, II: 128, 136, 156], күз күрмәс, колак ищетмәс ер 'место, о котором не слышали, не видели' [БХИ, II 1976: 164]; длину пути: таяк ташлам ер 'расстояние, на которое можно палку бросить' [БХИ 1976, II: 157]; пение соловья: монлоларзың моңуон баса, моңһһоз̧арзың күзен аса 'печальных утешит, беспечных отрезвит' [БХИ 1976, II: 136], живой воды: йән үлтерә, йән терелтә торван шифаль hыу 'убивающая душу, оживляющая душу целебная вода' 
[БХИ 1976, II: 86]; пространство мифического противника: йорондай вына ерзљн торондай вына төтөн сыва 'из незаметного места еле-еле видный дым идет’ [БХИ 1976, I: 263], үтеп йөрөй алмаслькк кара урман 'непроходимый черный лес' [БХИ 1976, І: 270] и т. д.

Для языка башкирских волшебных сказок характерны и более сложные формульные конструкции, например, подчеркивающие бедность семьи: hиң̧ә ашатырzа ашыбызз, һуйырга малыббыз, асттыңа түшәргә кейезебез, өстөңз ябырга юрваныбыз, баш астыңца һальрва мендәребез̧ юж 'у нас нет еды, чтобы тебя накормить, нет скотины, чтобы зарезать на мясо, нет кошмы, куда бы ты мог лечь, нет одеяла, чтобы ты мог укрываться, нет подушки под твою голову класть' [БХИ 1976, II: 245-246]; трудность задания: күккә еткән һез̧зең йорттан минең йортка тиклем ульци хрусталь күпер һалдырһын, уның астылнан hөт, бал йылzаһы авып ятиын. Күперзең ике явында төрлө емеш авастары Yс̧еn, бешеп, емештәре ергә төшөп ултырһын, һандугастар туктау hыз haüрап торһондар 'пусть твой сын от вашего дома до моего дома построит высотой до неба хрустальный мост, чтобы под мостом текли молочная и медовая реки. С обеих сторон моста чтобы фруктовые деревья росли, а фрукты поспевали и на землю падали, чтобы там безостановочно соловьи пели' [БХИ 1976, I: 110]; место нахождения души мифического противника: анауында күл бар, күл өстөөндә утрауз̧а тирәк үсееп ултыра. Шул тирәк башындавы ояла йомортка бар. Шул йоморткала минең йәнем

\section{Литература}

Алиева 1986 - Алиева А. И. Поэтика и стиль волшебных сказок адыгских народов. М.: Наука, 1986. 279 с.

БХИ 1976, I - Башкорт халык ижады. Әкиәттәр. 1-се китап (= Башкирское народное творчество. Сказки. Кн. 1) / төз . М. Х. Минһажетдинов һәм Ә. И. Харисов; инеш мәкәлә авт. М. Х. Минһажетдинов; аңлатм. авт. Л. Г. Бараг менән М. Х. Минһажетдинов. Өфө: Башкортостан китап нәшриәте, 1976. 376 б.

БХИ 1976, II — Башкорт халык ижады. Әкиәттәр. 2-се китап (=Башкирское народное творчество. Сказки. Кн. 2) / Төз̧. М. Х. Минһа- 'вон там есть озеро, на озере есть остров, а на острове растет тополь. На вершине тополя есть гнездо, в гнезде - яйцо. Вот в этом яйце находится моя душа' [БХИ 1976, I: 115]; минең йәнем бер hыуззын астында. Бер йәшник эсенә күгәрсен ике йомортка һалган, үрмәксе ау корван, йәнем шунда. Йоморткаларзы берәү зे таба алмай 'моя душа находится под водой. В один ящик голубь снесла два яйца, над ней паук свил паутину, там моя душа. Яйца никто не может найти' [БХИ 1976, I: 119] и т. д. Как видно из примеров, душа мифического противника находится либо в верхнем, либо в нижнем мире, и достать ее может только главный герой сказки.

\section{Заключение}

Изучение эпитетов в текстах башкирских волшебных сказок показало, что они действительно являются активно используемым в них тропом, способствующим раскрытию героя с разных сторон. Как показывают примеры, при характеристике героя и его верного друга-коня использованы эпитеты в основном с положительной оценкой. При описании одежды героя, его жилья, уровня жизни, социального статуса используются эпитеты, показывающие высшую степень его бедности, которые способствуют еще большей идеализации героя волшебной сказки, ибо для него важно не богатство, а нравственные ценности.

В статье также показаны выявленные в башкирских волшебных сказках простые и сложные структурные типы эпитетов башкирской волшебной сказки, которые закреплены соответствующими примерами.

жетдинов һәм Ә. И. Харисов. Инеш мәкәлә авт. М. Х. Минһажетдинов. Аңлатмалар авторззары Л. Г. Бараг менән М. Х. Минһажетдинов. Өфө: Башкортостан китап нәшриәте, 1976. 376 б.

Галяутдинов 2000 - Галяутдинов И. Г. Два века башкирского литературного языка. Уфа: Гилем, 2000. 448 с.

Демчинова 2003 - Демчинова М. А. Алтайская волшебная сказка. Горно-Алтайск: Изд-во ГАГУ, 2003. 164 с.

Зайнуллин 1974 - Зайнуллин М. В. Употребление временных и модальных форм глагола в языке башкирских сказок // Фольклор народов РСФСР. Вып. 1 / отв. ред. проф. 
Т. М. Акимова и проф. Л. Г. Бараг. Уфа: Башкирский гос. ун-т, 1974. С. 92-98.

Зайнуллин 1976 - Зайнуллин М. В. О выражении экспрессивности в башкирских народных сказках // Фольклор народов РСФСР. Вып. 2 / отв. ред. проф. Т. М. Акимова и проф. Л. Г. Бараг. Уфа: Башкирский гос. унт, 1976. C. 45-49.

Зарипов 2008 - Зарипов Н. Т. Башкирские богатырские сказки. Уфа: Гилем, 2008. 240 с.

Зинурова 2009 - Зинурова Р. Р. Батырзар тураһындағы башкорт әкиәттәрендә һүрәтләү саралары: гипербола һәм сағыштырыу (= Художественно-изобразительные средства в башкирских богатырских сказках: гипербола и сравнения) // Актуальные проблемы современной фольклористики: матлы междунар. науч.-практ. конф. (г. Казань, 29 июня 2009 г.). Казань: ИЯЛИ им. Г. Ибрагимова АН РТ, 2009. С. 215-217.

Киекбаев 1966 - Киекбаев Дж. Г. Хәзерге башкорт теленең лексикаһы һәм фразеологияһы (= Лексика и фразеология современного башкирского языка). Өфө: Башкортостан китап нәшриәте, 1966. 275 б.

Кульсарина 2009 - Кульсарина Г. Г. Язык и стиль башкирских народных сказок. Уфа: БашГУ, 2009. 144 с.

\section{References}

Alieva A. I. Adyghe Magic Tales: Poetics and Style. Moscow: Nauka, 1986. 279 p. (In Russ.)

Demchinova M. A. Altaian Magic Tale. Gorno-Altaysk: Gorno-Altaysk State University, 2003. 164 p. (In Russ.)

Galyautdinov I. G. The Two Centuries of Literary Bashkir. Ufa: Gilem, 2000. 448 p. (In Russ.)

Kiekbaev J. G. Modern Bashkir: Vocabulary and Phraseology. Ufa: Bashkortostan Book Publ., 1966. 275 p. (In Bash.)

Kulsarina G. G. Bashkir Folklore Texts: Ethnolinguistic View of the World. Ufa: Kitap, 2020. 352 p. (In Russ.)

Kulsarina G. G. Bashkir Folktales: Language and Style. Ufa: Bashkir State University, 2009. 144 p. (In Russ.)

Meshcheryakova O. A. Magic tale: linguistic features of portrait and its functions. In: Dobrovolskaya V. E. et al. (comps.) The Third National Congress of Folklorists. Collected scholarly papers (Moscow; February 3-7, 2014). In 5 vols. Vol. 1: Topical Issues of Folklore Studies in Russia. Moscow: Roskultproekt, 2017. Pp. 358-367. (In Russ.)

Mingazhetdinov M. Kh., Kharisov A. I. (comps.), Zaripov N. T. (ed.) Bashkir Folklore: Tales.
Кульсарина 2020 - Кульсарина Г. Г. Этноязыковая картина мира в текстах башкирского фольклора. Уфа: Китап, 2020. 352 с.

Надршина 1986 - Нәзериина Ф. А. Халык хәтере (= Память народа). Өфө: Башкортостан китап нәшриәте, 1986. 192 б.

Мещерякова 2017 - Мещерякова О. А. Языковые особенности портрета и его функции в волшебной сказке // III Всероссийский конгресс фольклористов (г. Москва, 3-7 февраля 2014 г.), сб. науч. ст. в 5 т. Т. 1: Актуальные проблемы российской фольклористики / сост. В. Е. Добровольская, Е. А. Дорохова, А. Б. Ипполитова. М.: Роскультпроект, 2017. C. $358-367$.

Псянчин 1984 - Псянчин В. Ш. Телдең күркәмлек саралары: укытыусылар өсөн кулланма (= Изобразительные средства языка). Өфө: Башкортостан китап нәшриәте, 1984. 128 б.

Разумова 1991 - Разумова И. А. Стилистическая обрядность русской волшебной сказки. Петрозаводск: Карелия, 1991. 163 с.

Ягафарова 2016 - Ягафарова Г. Н. Фольклорные имена: о чем они говорят (на примере башкирских богатырских сказок) // Известия Уральского федерального университета. Серия 2. Гуманитарные науки. Т. 18. 2016. № 2 (151). C. 155-169.

Book 1. Ufa: Bashkortostan Book Publ., 1976. 376 p. (In Bash.)

Mingazhetdinov M. Kh., Kharisov A. I. (comps.), Zaripov N. T. (ed.) Bashkir Folklore: Tales. Book 2. Ufa: Bashkortostan Book Publ., 1976. 376 p. (In Bash.)

Nadrshina F. A. Memory of the People. Ufa: Bashkortostan Book Publ., 1986. 192 p. (In Bash.)

Psyanchin V. Sh. Artistic Tools of the Language. Ufa: Bashkortostan Book Publ., 1984. 128 p. (In Bash.)

Razumova I. A. Russian Magic Tale: Stylistic Ritualism. Petrozavodsk: Kareliya, 1991. 163 p. (In Russ.)

Yagafarova G. N. Folklore names: what they speak about (with reference to Bashkir heroic tales). Ural Federal University Journal. Series 2. Humanities and Arts. 2016. Vol. 18. No. 2 (151). Pp. 155-169. (In Russ.)

Zaripov N. T. Bashkir Heroic Tales. Ufa: Gilem, 2008. 240 p. (In Russ.)

Zaynullin M. V. Bashkir folktales: expressive means revisited. In: Akimova T. M., Barag L. G. (eds.) Folklore of the RSFSR's Peoples. Vol. 2. Ufa: Bashkir State University, 1976. Pp. 45-49. (In Russ.) 
Zaynullin M. V. The language of Bashkir folktales: tense and modal forms. In: Akimova T. M., Barag L. G. (eds.) Folklore of the RSFSR's Peoples. Vol. 1. Ufa: Bashkir State University, 1974. Pp. 92-98. (In Russ.)

Zinurova R. R. Artistic tools of Bashkir heroic tales: hyperbole and comparison. In: Topical Issues of Contemporary Folklore Studies. Conference proceedings (Kazan; June 29, 2009). Kazan: Ibragimov Institute of Language, Literature and History (Tatarstan Academy of Sciences), 2009. Pp. 215-217. (In Bash.) 